\title{
Microglia and Autism Spectrum Disorder: Overview of Current Evidence and Novel Immunomodulatory Treatment Options
}

\author{
Jung Won Kim', Ji Yeon Hong $^{2}$, Seung Min Bae ${ }^{3}$ \\ ${ }^{1}$ Department of Psychiatry and Behavioral Neurobiology, University of Alabama at Birmingham, Birmingham, AL, USA, ${ }^{2}$ Department of Medicine, \\ Severance Biomedical Science Institute, Yonsei University College of Medicine, Seoul, ${ }^{3}$ Department of Psychiatry, Gachon University Gil Medical \\ Center, Gachon University College of Medicine, Incheon, Korea
}

\begin{abstract}
Autism spectrum disorder is a rapidly increasing heterogeneous neurodevelopmental syndrome, remarked by persistent deficit in social communication, and restricted, repetitive patterns of behavior and interest. Lately, maternal immune activation and micgroglial dysfunction in the developing brain have been gaining mounting evidence and leading to studies of various novel agents as potential treatment options. A few immunomodulatory treatment options-luteolin, minocycline, suramin, vitamin D, gut microbiota-are discussed in the current article, regarding the current understanding of their mechanisms and evidence for potential clinical use. More studies are warranted to understand their exact mechanisms of action and to verify efficacy and safety in human subjects.
\end{abstract}

KEY WORDS: Autism spectrum disorder; Maternal immune activation; Microglia; Immunomodulatory therapy.

\section{INTRODUCTION}

Characterized by persistent deficit in social communication, and restricted, repetitive patterns of behavior and interest, autism spectrum disorder (ASD) is now one of the most commonly diagnosed neurodevelopmental disorders, with its latest prevalence measured at 1 out of 68 children aged 8 years. ${ }^{1)}$ The prevalence of the disorder has rapidly and continuously been increasing. ') Some studies suggest an even higher prevalence of $2.64 \%{ }^{2)}$ In order to account for its rapidly increasing prevalence over the last couple of decades, many etiologic theories have been proposed with varying degrees of supporting evidence. Some of the popular theories include increased public awareness, higher diagnostic rates, environmental changes, etc. ${ }^{3-5)}$ However, in large, exact pathogenesis

Received: January 3, 2018 / Revised: March 12, 2018

Accepted: April 5, 2018

Address for correspondence: Seung Min Bae, MD

Department of Psychiatry, Gachon University Gil Medical Center, Gachon University College of Medicine, 21 Namdong-daero,

774beon-gil, Namdong-gu, Incheon 21565, Korea

Tel: +82-32-1577-2299, Fax: +82-32-472-3396

E-mail: mdbae@gilhospital.com

ORCID: https://orcid.org/0000-0003-3732-6824 still remains unknown, ${ }^{6}$ ) and so far, no biomarker has been identified with reliable diagnostic or prognostic values. ${ }^{7)}$ A growing body of evidence indicates that infectious or inflammatory immune activation in pregnant mothers lead to higher risk of neurodevelopmental disorders including ASD in the offspring. ${ }^{8)}$ To account for such findings, maternal immune activation (MIA) and resulting microglial dysfunction in the developing brain have been studied. ${ }^{9)}$ Meanwhile, a few novel agents targeting microglial activation in particular have shown positive results in animal studies. ${ }^{10-12)}$ In this article, we aim to overview current understanding of MIA and microglial dysfunction as a potential cause for a subtype of ASD and novel treatment ideas.

\section{MATERNAL IMMUNE ACTIVATION}

The potential role of MIA in increased risk for ASD in the offspring has been repeatedly reported in studies of rodent and rhesus monkey. ${ }^{13,14)}$ Increased maternal interleukin (IL)-6 induced by inflammation has been shown to directly cause changes in transcription in the frontal cortex of the offspring. ${ }^{15)}$ In animal studies, maternal immune-activated pro-inflammatory cytokines, such as

(ㄷ) This is an Open-Access article distributed under the terms of the Creative Commons Attribution Non-Commercial License (http://creativecommons.org/licenses/by-nc/4.0) which permits unrestricted non-commercial use, distribution, and reproduction in any medium, provided the original work is properly cited. 
IL-1 $\beta$, IL-6, tumor necrosis factor (TNF)- $\alpha$ have been shown to readily cross over to the fetal brain ${ }^{16,17)}$ and cause direct impact on the fetal neurodevelopment. ${ }^{18)}$ Several animal studies have demonstrated that autism-like behaviors were observed in the offspring, following the exposure of pregnant mothers to the polyinosinic:polycytidylic acid (poly I:C)-a viral mimetic, an influenza virus, or the lipopolysaccharides (LPS) - a bacterial component. ${ }^{19)}$ Growing evidence for the presence of inflammation in the fetal brain includes microglial activation and proliferation in addition to the presence of increased pro-inflammatory cytokines. ${ }^{20,21)}$

\section{MICROGLIA}

Microglia are well-known as macrophages of the central nervous system (CNS), whose major function is ambient surveillance and activation during insults to CNS, such as damage, infection, or disease. ${ }^{22)}$ Microglial progenitors are believed to arrive and occupy the developing fetal brain, preceding the completion of the blood brain barrier (BBB). ${ }^{23)}$ Unlike traditionally believed, the non-inflammatory role of microglia-synaptic pruning-has been implicated more as essential part of CNS development. $^{24,25)}$ Therefore, in addition to inflammatory role of microglia implicated in dysfunctional microglial activation and pathogenesis of $\mathrm{ASD}^{26)}$ dysfunction in such microglia-mediated synaptic pruning process during the neural development in the offspring has been associated with neurodevelopmental disorders, such as ASD. ${ }^{27)}$ Studies also demonstrate that disruption in such essential function of microglia during neural development at any time from pregnancy to early postnatal period can lead to neurodevelopmental disorders, such as ASD. ${ }^{28)}$

\section{IMMUNOMODULATORY TREATMENT}

Along with accumulating evidence for MIA and microglial impact as a potential etiologic cause for a subtype of ASD, a few novel treatment options have been proposed and studied in animal and/or human trials. Some of the most studied agents include luteolin, minocycline, suramin, vitamin $D$, and gut microbiota, which will be reviewed here (Table 1 and Fig. 1).

\section{Luteolin}

Luteolin is an antioxidant known to block microglial activation $^{29)}$ and reduce the neurotoxic effect. ${ }^{30)}$ Luteolin appears to exert its effects by dampening histamine, IL-6, IL-8, TNF, tryptase from mast cells. ${ }^{31)}$ It is considered safe with minimal to no side effects. ${ }^{32-35)}$ In an animal model study (mice ASD), luteolin has been shown to attenuate autism like behaviors in mice. ${ }^{33)}$ In the most recent animal studies, luteolin has been observed to decrease the levels

Table 1. Overview of immunomodulatory agents for autism spectrum disorder (ASD)

\begin{tabular}{|c|c|c|c|c|}
\hline $\begin{array}{l}\text { Name of } \\
\text { treatment }\end{array}$ & Mechanism of action & Effects & Side effects & Trials \\
\hline Luteolin & $\begin{array}{l}\text { Antioxidant } \\
\text { Block microglial activation }^{29)} \\
\text { Reduce neurotoxic effect }\end{array}$ & $\begin{array}{l}\text { Decrease inflammatory } \\
\text { cytokines, TNF- } \alpha, \text { IL-1 } \beta^{10,31)}\end{array}$ & $\begin{array}{l}\text { Considered safe with minimal } \\
\text { to no side effects }\end{array}$ & $\begin{array}{l}\text { Attenuated autism-like } \\
\text { behaviors in mice } \\
\text { Improved sociability in } \\
\text { humans }^{10,34,35)}\end{array}$ \\
\hline Minocycline & $\begin{array}{l}\text { Tetracycline antibiotic } \\
\text { Pleotropic anti-inflammatory } \\
\text { and neuroprotective } \\
\text { activities }^{36,37)}\end{array}$ & $\begin{array}{l}\text { Modulate microglial } \\
\text { activation }^{39,40)}\end{array}$ & $\begin{array}{l}\text { Deemed safe (as add-on to } \\
\text { risperidone for children with } \\
\text { ASD) }{ }^{44)}\end{array}$ & $\begin{array}{l}\text { Improved autistic, anxiety } \\
\text { behavior in mice }{ }^{11,41)} \\
\text { Inconsistent results in } \\
\text { humans }{ }^{43,44)}\end{array}$ \\
\hline Suramin & $\begin{array}{l}\text { Competitive inhibition of } \\
\text { purinergic signaling }\end{array}$ & $\begin{array}{l}\text { Recover dysregulated } \\
\text { purinergic metabolism }^{12)}\end{array}$ & $\begin{array}{l}\text { Tolerated without major } \\
\text { adverse effects (in pilot trial } \\
\text { for children with ASD) }{ }^{48)}\end{array}$ & $\begin{array}{l}\text { Improved core symptoms of } \\
\text { autism in mice }{ }^{12,46,47)} \text { and } \\
\text { humans }\end{array}$ \\
\hline Vitamin D & Active neuro-steroid. & $\begin{array}{l}\text { Modulate pro-inflammatory } \\
\text { cytokine release from } \\
\text { microglia }^{51,52)}\end{array}$ & & Mixed results in RCTs ${ }^{53,54)}$ \\
\hline $\begin{array}{l}\text { Gut } \\
\text { microbiota }\end{array}$ & Microbiome & $\begin{array}{l}\text { Modulate environmental } \\
\text { and genetic risk factors for } \\
\mathrm{ASD}^{62,63)}\end{array}$ & & $\begin{array}{l}\text { Bacteroides fragilis improved } \\
\text { behavioral disturbance in } \\
\text { mice }^{61)}\end{array}$ \\
\hline
\end{tabular}

TNF, tumor necrosis factor; IL, interleukin; RCT, randomized controlled trial. 


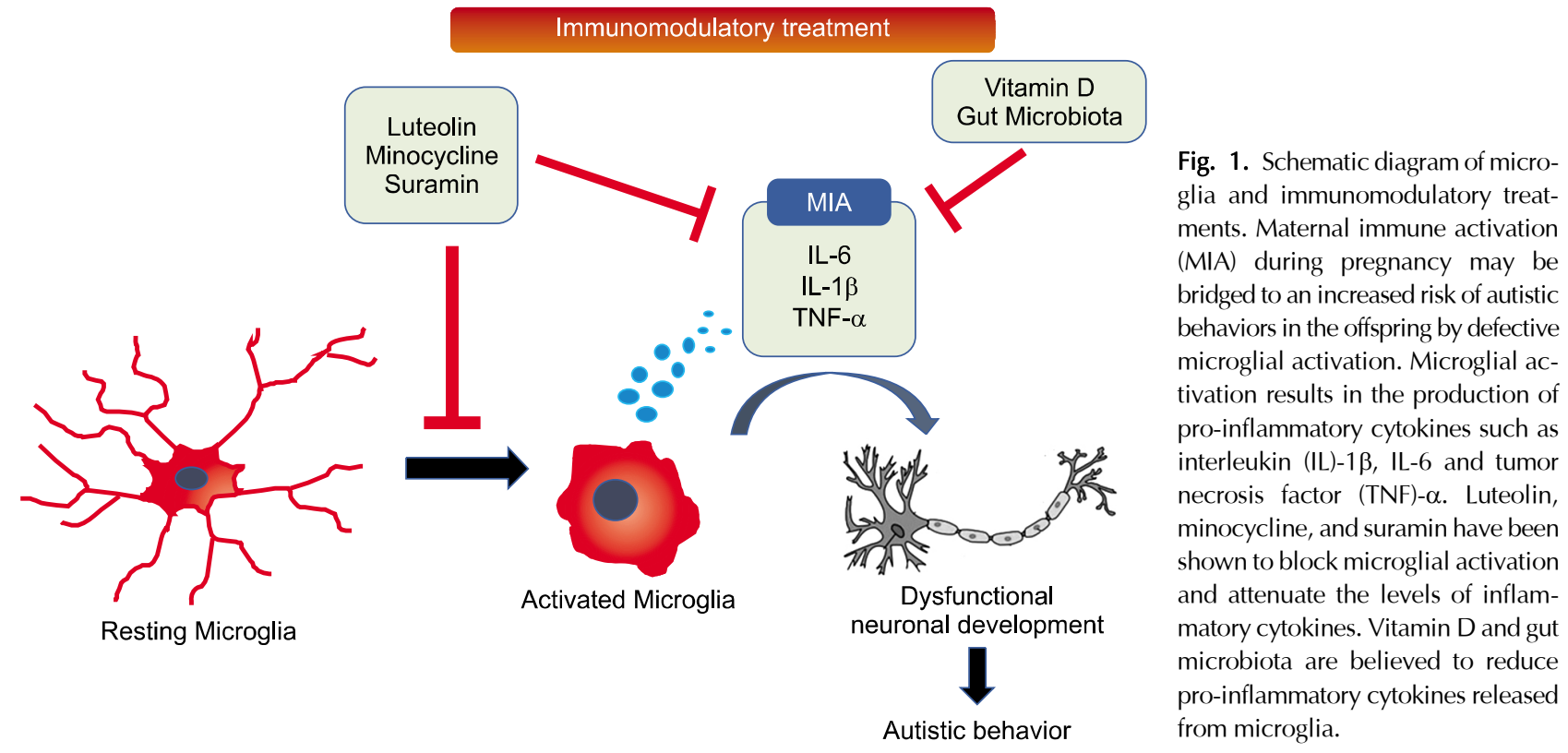

of inflammatory cytokines, TNF- $\alpha$ and IL-1 $\beta$ in valproic acid (VPA)-induced ASD animal models. ${ }^{10)}$ In particular, the study by Bertolino et $a / .{ }^{10)}$ included the results of animal experiments as well as that of clinical trial of a 10-year-old boy with ASD. The boy showed improved symptoms overall, but particularly in the social area. He also showed significant improvement in enuresis, a most difficult symptom reported by parents. In clinical studies, luteolin also has proven effective in ameliorating comorbid symptoms of ASD patients, such as attention and sociability. ${ }^{34,35)}$

\section{Minocycline}

Minocycline is a tetracycline antibiotic; whose mechanism is via its known pleotropic anti-inflammatory and neuroprotective activities. ${ }^{36,37)}$ Another proposed key mechanism of action for minocycline is via hindering matrix metalloproteinase (MMP). ${ }^{38)}$ A growing evidence has suggested the modulating effect of minocycline in microglia activation. ${ }^{39,40)}$ A series of animal studies have proven minocycline as an effective treatment for autistic behaviors. In their study with patDp/+ mice ASD model (human 15q11-q13), Shigemori et al. ${ }^{41)}$ showed that prenatal treatment with minocycline led to recovery of microglial activation markers as well as improved anxiety behaviors. In VPA-induced rat ASD model, minocycline was also shown to improve autistic behaviors. ${ }^{11)}$ Minocycline has also been shown promising in few yet accumulating human trials. In an open-label add-on trial for fragile $X$ syndrome, the most common known genetic cause of ASD, minocycline significantly improved irritability in patients, as evidenced by Aberrant Behavior Checklist-Community (ABC-C), irritability subscale. ${ }^{42)}$ Human trials, however, have not shown consistent results. A small pilot trial $(n=10)$ with minocycline up to six months showed only minimal improvement, and neither yielded any significant behavioral improvement in ASD nor showed any observable changes in key inflammatory cytokines, such as IL-1 $\beta$, IL-6, TNF- $\alpha$, or MMP. ${ }^{43)}$ More lately, however, minocycline was deemed a safe and effective choice as an add-on to risperidone for children with ASD, based on ABC-C irritability subscale. ${ }^{44)}$ Further studies looking at clinical utility of minocycline as a monotherapy or an add-on to risperidone for symptoms of ASD in not only child/adolescent but also adult patients are needed.

\section{Suramin}

Suramin is best known as a treatment for African sleeping sickness, whose mechanism of action is via competitive inhibition of purinergic signaling. ${ }^{45)}$ In the first study of its kind, Naviaux et al. ${ }^{46)}$ showed significant effect of suramin on improving core behavioral and comorbid symptoms in poly I:C-exposed MIA model of ASD mice. In their subsequent study, Naviaux et al. ${ }^{12)}$ demonstrated that a single dose of suramin was able to improve core 
symptoms of autism, such as sociality, novelty-seeking, as well as recover dysregulated purinergic metabolism in poly I:C-exposed MIA model of adult ASD mice. Antipurinergic therapy using suramin also proved effective for improving autistic features in fragile $X$ mouse model, showing its efficacy across different etiologic models of ASD. ${ }^{47)}$ More recently, in the first translational pilot trial, low-dose suramin treatment was well tolerated without major adverse effects and associated with significant improvement in core symptoms of ASD in a small number of child and adolescent male patients. ${ }^{48)}$ A study has shown that suramin also inhibits spinal cord microglia activation followed by long-term hyperalgesia. ${ }^{49)}$ The exact mechanism of action of suramin on microglia with regards to ASD is yet unclear and requires further studies.

\section{Vitamin D}

Vitamin D deficiency has been increasingly implicated as a risk factor for development of ASD. ${ }^{50)}$ Vitamin D is an active neuro-steroid, believed to modulate pro-inflammatory cytokine release from microglia. ${ }^{51,52)}$ Despite being seemingly one of the most studied supplemental treatment for ASD, studies targeting use of vitamin D as a treatment or prophylaxis for ASD; however, have been yielding mixed results. One of the first randomized controlled trials (RCTs) involving a high dose vitamin D supplementation in child ASD patients showed significant improvement in symptoms. ${ }^{53)}$ However, another RCT involving a lower dose vitamin D supplementation in child ASD patients failed to show consistent benefits. ${ }^{54)}$ Furthermore, a recent study showed low serum levels of vitamin D in 60 patients with ASD. ${ }^{55)}$ Such discrepancy and inconsistent results from trials have been speculated to originate from failures to account for various forms of vitamin D metabolites with different bioavailability as well as its receptors and binding proteins. ${ }^{50)}$ Further studies with methodological designs that would allow delineating such discrepancies are called for.

\section{Gut microbiota}

It is widely known that ASD commonly and frequently presents with gastrointestinal disturbances. ${ }^{56)}$ Studies also have suggested relationship with symptom severity in ASD patients and gastrointestinal disturbances. ${ }^{57)}$ Gut bacteria have been frequently implicated in $\mathrm{ASD},{ }^{58)}$ and animal and human studies have demonstrated its correla- tion with behavioral disturbances. ${ }^{59-61)}$ Interestingly, modeling MIA-induced ASD offspring in mice resulted not only in behavioral disturbance but also alterations in gut microbiota, which were however reversed by treatment with Bacteroides fragilis ( $B$. fragilis). ${ }^{62)}$ More recent findings have suggested that the microbiome plays a crucial role in modulating environmental and genetic risk factors for development of ASD. ${ }^{63,64)}$ The relationship between microbiota and microglial activation has lately been further studied. Short-chain fatty acids, microbiota-derived bacterial fermentation products, are identified to regulate microglia homeostasis, and the depletion of short-chain fatty acid receptors mimics microglia defects. ${ }^{65)}$ Further clinical studies involving patients with ASD are called for based on this finding.

\section{CONCLUSION}

ASD is an immense heterogeneous syndrome that is believed to be a product of complex interactions among many known and unknown risk factors. MIA-induced microglial activation in the offspring brain has been implicated as an important etiologic mechanism for a subset of ASD, opening windows into a few novel treatment options. A few immunomodulatory treatment optionssuch as luteolin, minocycline, suramin, vitamin D, gut microbiota-have been discussed in our paper about the current understanding of their mechanisms and the mounting evidence for potential clinical use. Although many of these novel treatment options appear to be promising and hopeful, their exact mechanisms of action and clear explanation as to how microglia activation is being recruited and modulated upon each of the optional treatments are to be further studied, and more translational trials are in order to verify efficacy and safety in human subjects. Given that immunomodulatory treatment options described here modulate autistic behaviors, it is plausible to test whether these treatments can be mediated by microglial activation. Such further clinical/experimental studies could potentially allow for better understanding and development of treatment options specifically targeting a process or cascades involved in microglial activation and/or dysfunction.

\section{REFERENCES}

1. Developmental Disabilities Monitoring Network Surveillance 
Year 2010 Principal Investigators; Centers for Disease Control and Prevention (CDC). Prevalence of autism spectrum disorder among children aged 8 years - autism and developmental disabilities monitoring network, 11 sites, United States, 2010. MMWR Surveill Summ 2014;63:1-21.

2. Kim YS, Leventhal BL, Koh YJ, Fombonne E, Laska E, Lim EC, et al. Prevalence of autism spectrum disorders in a total population sample. Am J Psychiatry 2011;168:904-912.

3. King MD, Bearman PS. Socioeconomic status and the increased prevalence of autism in California. Am Sociol Rev 2011;76:320-346.

4. King M, Bearman P. Diagnostic change and the increased prevalence of autism. Int I Epidemiol 2009;38:1224-1234.

5. Kinney DK, Miller AM, Crowley DJ, Huang E, Gerber E. Autism prevalence following prenatal exposure to hurricanes and tropical storms in Louisiana. J Autism Dev Disord 2008; 38:481-488.

6. Currenti SA. Understanding and determining the etiology of autism. Cell Mol Neurobiol 2010;30:161-171.

7. Anderson GM. Autism biomarkers: challenges, pitfalls and possibilities. J Autism Dev Disord 2015;45:1103-1113.

8. Solek CM, Farooqi N, Verly M, Lim TK, Ruthazer ES. Maternal immune activation in neurodevelopmental disorders. Dev Dyn 2018;247:588-619.

9. Nardone $\mathrm{S}$, Elliott $\mathrm{E}$. The interaction between the immune system and epigenetics in the etiology of autism spectrum disorders. Front Neurosci 2016;10:329.

10. Bertolino B, Crupi R, Impellizzeri D, Bruschetta G, Cordaro $\mathrm{M}$, Siracusa R, et al. Beneficial effects of co-ultramicronized palmitoylethanolamide/luteolin in a mouse model of autism and in a case report of autism. CNS Neurosci Ther 2017;23: $87-98$.

11. Kumar H, Sharma B. Minocycline ameliorates prenatal valproic acid induced autistic behaviour, biochemistry and blood brain barrier impairments in rats. Brain Res 2016;1630: 83-97.

12. Naviaux JC, Schuchbauer MA, Li K, Wang L, Risbrough VB, Powell SB, et al. Reversal of autism-like behaviors and metabolism in adult mice with single-dose antipurinergic therapy. Trans/ Psychiatry 2014;4:e400.

13. Bauman MD, losif AM, Smith SE, Bregere C, Amaral DG, Patterson PH. Activation of the maternal immune system during pregnancy alters behavioral development of rhesus monkey offspring. Biol Psychiatry 2014;75:332-341.

14. Machado CJ, Whitaker AM, Smith SE, Patterson PH, Bauman MD. Maternal immune activation in nonhuman primates alters social attention in juvenile offspring. Biol Psychiatry 2015; 77:823-832.

15. Smith SE, Li J, Garbett K, Mirnics K, Patterson PH. Maternal immune activation alters fetal brain development through interleukin-6. J Neurosci 2007;27:10695-10702.

16. Lin D, Smith MA, Champagne C, Elter J, Beck J, Offenbacher S. Porphyromonas gingivalis infection during pregnancy in- creases maternal tumor necrosis factor alpha, suppresses maternal interleukin-10, and enhances fetal growth restriction and resorption in mice. Infect Immun 2003;71:5156-5162.

17. Golan H, Levav T, Mendelsohn A, Huleihel M. Involvement of tumor necrosis factor alpha in hippocampal development and function. Cereb Cortex 2004; 14:97-105.

18. Gilmore JH, Fredrik Jarskog L, Vadlamudi S, Lauder JM. Prenatal infection and risk for schizophrenia: IL-1beta, IL-6, and TNFalpha inhibit cortical neuron dendrite development. Neuropsychopharmacology 2004;29:1221-1229.

19. Patterson PH. Immune invo/vement in schizophrenia and autism: etiology, pathology and animal models. Behav Brain Res 2009;204:313-321.

20. Li X, Chauhan A, Sheikh AM, Patil S, Chauhan V, Li XM, et al. Elevated immune response in the brain of autistic patients. $J$ Neuroimmunol 2009;207:111-116.

21. Vargas DL, Nascimbene C, Krishnan C, Zimmerman AW, Pardo CA. Neuroglial activation and neuroinflammation in the brain of patients with autism. Ann Neurol 2005;57:67-81.

22. Casano AM, Peri F. Microglia: multitasking specialists of the brain. Dev Cell 2015;32:469-477.

23. Ginhoux F, Greter M, Leboeuf M, Nandi S, See P, Gokhan S, et al. Fate mapping analysis reveals that adult microg/ia derive from primitive macrophages. Science 2010;330:841-845.

24. Harry GJ. Microglia during development and aging. Pharmacol Ther 2013;139:313-326.

25. Schafer DP, Lehrman EK, Kautzman AG, Koyama R, Mardinly AR, Yamasaki R, et al. Microglia sculpt postnatal neural circuits in an activity and complement-dependent manner. Neuron 2012;74:691-705.

26. Williamson LL, Sholar PW, Mistry RS, Smith SH, Bilbo SD. Microglia and memory: modulation by early-life infection. J Neurosci 2011;:31:15511-15521.

27. Tang G, Gudsnuk K, Kuo SH, Cotrina ML, Rosoklija G, Sosunov A, et al. Loss of mTOR-dependent macroautophagy causes autistic-like synaptic pruning deficits. Neuron 2014; 83:1131-1143.

28. Takano T. Role of microg/ia in autism: recent advances. Dev Neurosci 2015;37:195-202.

29. Dirscherl K, Karlstetter M, Ebert S, Kraus D, Hlawatsch J, Walczak Y, et al. Luteolin triggers global changes in the microglial transcriptome leading to a unique anti-inflammatory and neuroprotective phenotype. J Neuroinflammation 2010; $7: 3$.

30. Chen HQ, Jin ZY, Wang XJ, Xu XM, Deng L, Zhao JW. Luteolin protects dopaminergic neurons from inflammation-induced injury through inhibition of microglial activation. Neurosci Lett 2008:448:175-179.

31. Kimata M, Shichijo M, Miura T, Serizawa I, Inagaki N, Nagai $\mathrm{H}$. Effects of luteolin, quercetin and baicalein on immunoglobulin e-mediated mediator release from human cultured mast cells. Clin Exp Allergy 2000;30:501-508.

32. Harwood M, Danielewska-Nikiel B, Borzelleca JF, Flamm 
GW, Williams GM, Lines TC. A critical review of the data related to the safety of quercetin and lack of evidence of in vivo toxicity, including lack of genotoxic/carcinogenic properties. Food Chem Toxicol 2007:45:2179-2205.

33. Parker-Athill E, Luo D, Bailey A, Giunta B, Tian J, Shytle RD, et al. Flavonoids, a prenatal prophylaxis via targeting JAK2/STAT3 signaling to oppose IL-6/MIA associated autism. J Neuroimmunol 2009;217:20-27.

34. Theoharides TC, Asadi S, Panagiotidou S. A case series of a luteolin formulation (NeuroProtek®) in children with autism spectrum disorders. Int J Immunopathol Pharmacol 2012;25: 317-323.

35. Taliou A, Zintzaras E, Lykouras L, Francis K. An open-label pilot study of a formulation containing the anti-inflammatory flavonoid luteolin and its effects on behavior in children with autism spectrum disorders. Clin Ther 2013;35:592-602.

36. Yong VW, Wells J, Giuliani F, Casha S, Power C, Metz LM. The promise of minocycline in neurology. Lancet Neurol 2004;3: 744-751.

37. Regen F, Le Bret N, Hildebrand M, Herzog I, Heuser I, Hellmann-Regen J. Inhibition of brain retinoic acid catabolism: a mechanism for minocycline's pleiotropic actions? World J Biol Psychiatry 2016;17:634-640.

38. Siller SS, Broadie K. Matrix metalloproteinases and minocycline: therapeutic avenues for fragile $X$ syndrome. Neural Plast 2012;2012:124548.

39. Zhu F, Zheng Y, Ding YQ, Liu Y, Zhang X, Wu R, et al. Minocycline and risperidone prevent microglia activation and rescue behavioral deficits induced by neonatal intrahippocampal injection of lipopolysaccharide in rats. PLoS One 2014;9:e93966.

40. Kumar A, Vashist A, Kumar P, Kalonia H, Mishra J. Potential role of licofelone, minocycline and their combination against chronic fatigue stress induced behavioral, biochemical and mitochondrial alterations in mice. Pharmacol Rep 2012;64: 1105-1115.

41. Shigemori T, Sakai A, Takumi T, Itoh Y, Suzuki H. Altered microglia in the amygdala are involved in anxiety-related behaviors of a copy number variation mouse model of autism. J Nippon Med Sch 2015;82:92-99.

42. Paribello C, Tao L, Folino A, Berry-Kravis E, Tranfaglia M, Ethell IM, et al. Open-label add-on treatment trial of minocycline in fragile X syndrome. BMC Neurol 2010;10:91.

43. Pardo CA, Buckley A, Thurm A, Lee LC, Azhagiri A, Neville $\mathrm{DM}$, et al. A pilot open-label trial of minocycline in patients with autism and regressive features. J Neurodev Disord 2013; 5:9.

44. Ghaleiha A, Alikhani R, Kazemi MR, Mohammadi MR, Mohammadinejad P, Zeinoddini A, et al. Minocycline as adjunctive treatment to risperidone in children with autistic disorder: a randomized, double-blind placebo-controlled trial. J Child Adolesc Psychopharmacol 2016;26:784-791.

45. Light AR, Wu Y, Hughen RW, Guthrie PB. Purinergic re- ceptors activating rapid intracellular Ca increases in microglia. Neuron Glia Biol 2006;2:125-138.

46. Naviaux RK, Zolkipli Z, Wang L, Nakayama T, Naviaux JC, Le $\mathrm{TP}$, et al. Antipurinergic therapy corrects the autism-like features in the poly(IC) mouse model. PLoS One 2013;8:e57380.

47. Naviaux JC, Wang L, Li K, Bright AT, Alaynick WA, Williams KR, et al. Antipurinergic therapy corrects the autism-like features in the Fragile X (Fmr1 knockout) mouse model. Mol Autism 2015;6:1.

48. Naviaux RK, Curtis B, Li K, Naviaux JC, Bright AT, Reiner GE, et al. Low-dose suramin in autism spectrum disorder: a small, phase I/II, randomized clinical trial. Ann Clin Trans/ Neurol 2017:4:491-505.

49. Wu Y, Willcockson HH, Maixner W, Light AR. Suramin inhibits spinal cord microglia activation and long-term hyperalgesia induced by formalin injection. J Pain 2004;5:48-55.

50. Máčová L, Bičíková M, Ostatníková D, Hill M, Stárka L. Vitamin D, neurosteroids and autism. Physiol Res 2017;66 (Supplementum 3):S333-S340.

51. Dulla YA, Kurauchi Y, Hisatsune A, Seki T, Shudo K, Katsuki $\mathrm{H}$. Regulatory mechanisms of vitamin D3 on production of nitric oxide and pro-inflammatory cytokines in microglial BV-2 cells. Neurochem Res 2016:41:2848-2858.

52. Boontanrart M, Hall SD, Spanier JA, Hayes CE, Olson JK. Vitamin D3 alters microglia immune activation by an IL-10 dependent SOCS3 mechanism. J Neuroimmunol 2016;292: 126-136.

53. Saad K, Abdel-Rahman AA, Elserogy YM, Al-Atram AA, El-Houfey AA, Othman HA, et al. Randomized controlled trial of vitamin $D$ supplementation in children with autism spectrum disorder. J Child Psychol Psychiatry 2018;59:20-29.

54. Kerley CP, Power C, Gallagher L, Coghlan D. Lack of effect of vitamin D3 supplementation in autism: a 20-week, placebo-controlled RCT. Arch Dis Child 2017;102:1030-1036.

55. Altun H, Kurutaş EB, Şahin N, Güngör O, Findıkl $\mathrm{E}$. The levels of vitamin $D$, vitamin D receptor, homocysteine and complex B vitamin in children with autism spectrum disorders. Clin Psychopharmacol Neurosci 2017. http://www.cpn.or.kr/ journal/view.html?uid=707\&vmd=Full\&. [Epub ahead of print]

56. Buie T, Campbell DB, Fuchs GJ 3rd, Furuta GT, Levy J, Vandewater J, et al. Evaluation, diagnosis, and treatment of gastrointestinal disorders in individuals with ASDs: a consensus report. Pediatrics 2010;125 Supp/ 1:S1-S18.

57. Adams JB, Johansen LJ, Powell LD, Quig D, Rubin RA. Gastrointestinal flora and gastrointestinal status in children with autism: comparisons to typical children and correlation with autism severity. BMC Gastroenterol 2011;11:22.

58. Parracho HM, Bingham MO, Gibson GR, McCartney AL. Differences between the gut microflora of children with autistic spectrum disorders and that of healthy children. J Med Microbiol 2005;54:987-991.

59. Cryan JF, Dinan TG. Mind-altering microorganisms: the impact of the gut microbiota on brain and behaviour. Nat Rev 
Neurosci 2012;13:701-712.

60. Tillisch K, Labus J, Kilpatrick L, Jiang Z, Stains J, Ebrat B, et al. Consumption of fermented milk product with probiotic modulates brain activity. Gastroenterology 2013;144:1394-1401, 1401.e1-e4.

61. Logan AC, Jacka FN, Craig JM, Prescott SL. The microbiome and mental health: looking back, moving forward with lessons from allergic diseases. Clin Psychopharmacol Neurosci 2016; 14:131-147.

62. Hsiao EY, McBride SW, Hsien S, Sharon G, Hyde ER, McCue $\mathrm{T}$, et al. Microbiota modulate behavioral and physiological abnormalities associated with neurodevelopmental disorders. Cell 2013;155:1451-1463.

63. Vuong HE, Hsiao EY. Emerging roles for the gut microbiome in autism spectrum disorder. Biol Psychiatry 2017;81:411-423.

64. Kim S, Kim H, Yim YS, Ha S, Atarashi K, Tan TG, et al. Maternal gut bacteria promote neurodevelopmental abnormalities in mouse offspring. Nature 2017;549:528-532.

65. Erny D, Hrabě de Angelis AL, Jaitin D, Wieghofer $P$, Staszewski O, David E, et al. Host microbiota constantly control maturation and function of microglia in the CNS. Nat Neurosci 2015; 18:965-977. 